ISSN: $1979-4940$

E-ISSN : 2477-0124
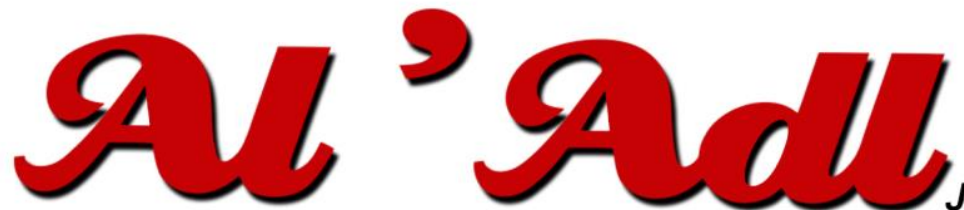

Jurnal Hukum

Editorial Office: Faculty of Law, Islamic University Of Kalimantan,

Jalan Adhyaksa No. 2 Kayutangi Banjarmasin, Kalimantan Selatan, Indonesia (70123)

Email:al_adl@uniska-bjm.ac.id

Web: http://ojs.uniska-bjm.ac.id

\title{
URGENCY OF SHULH IN DIVORCE CASE IN PANDEMIC COVID-19
}

\author{
Muhammad Andri \\ Fakultas Hukum Universitas Darul Ulum Jombang \\ Jl. KH. Abdurrahman Wahid No. 29. A Jombang \\ Email: mandri1976@gmail.com
}

\begin{abstract}
Submitted : 2 Desember 2020
Revised : 7 Januri 2021

Accepted : 20 Januari 2021

Published : 31 Januari 2021
\end{abstract}

(C) Licence by CC BY-NC-SA

\begin{abstract}
Abs tract
Building a family is the right of every citizen and is guaranteed by law (Article 28 B of the 1945 Amendment) The rampant divorce cases during the Covid-19 pandemic are very concerning, there is a significant increase in efforts that need to be made to shulh divorce cases during the Covid-19 pandemic outbreak There is a need for regulations as a legal umbrella, with the problem of the urgency of shulh in divorce cases in the Relig ious Courts during the Covid-19 Pandemic, the normative juridical research method used is a statutory approach and the analysis uses descriptive analysis of the results of this study that shulh divorce cases It is very important in the implementation of shulh in divorce cases in religious courts which have been based on online applications with the e litigation or e court model in this case in accordance with Perma No.1 of 2019 concerning Administration of Cases and Trials in Courts electronically, and can be seen from Supreme Court regulations in accordance with Perma No.3 of 2018 concerning Case Administration electronically in court then developed into an e-court, so with the covid-19 outbreak efforts to reconcile parties wishing to divorce were carried out online or using audio visual devices.
\end{abstract}

Keywords : Shulh, Divorce, Covid-19 Pandemic

\section{Abstrak}

Membangun keluarga merupakan hak setiap warga dan dijamin oleh undang undang (pasal 28 B UUD 1945 Amandemen) maraknya kasus perceraian disaat masa pandemi covid-19 sangat memprihatinkan terjadi peningkatan yang signifikan upaya yang perlu dilakukan men-shulh perkara peceraian di masa wabah pandemi covid-19 perlu adanya peraturan sebagai payung hukum, dengan permasalahan urgensi shulh dalam perkara perceraian di Pengadilan Agama selama masa Pandemi Covid-19, metode penelitian yuridis normatif yang digunakan dengan pendekatan perundang-undangan dan analisanya menggunakan metode desktiptif analisis hasil penelitian ini bahwa men-shulh perkara perceraian merupakan hal yang sangat penting dalam implementasinya shulh pada perkara perceraian dipengadilan agama telah berbasis aplikasi online dengan model e litigation atau e court dalam hal ini sesuai dengan Perma Nomor 1 Tahun 2019 tentang Administrasi Perkara dan Persidangan di Pengadilan secara Elektronik, serta dapat dilihat turunan peraturan Mahkamah Agung se suai dengan Perma Nomor 3 Tahun 2018 tentang Administrasi Perkara secara elektronik dipengadilan kemudian dikembang menjadi e-court, maka dengan adanya wabah covid-19 upaya mendamaikan para pihak yang ingin bercerai dilakukan dengan daring atau menggunakan perangkat audio visual. 
Kata Kunci : Shulh, Perceraian, Pandemi Covid-19:

\section{PENDAHULUAN}

Pasal 28 B UUD Amandemen menyatakan bahwa setiap orang berhak membentuk keluarga dan melanjutkan keturunan melalui perkawinan yang sah. Peran dan Fungsi Peradilan Agama sesuai dengan ketentuan yang tertuang dalam Pasal 49 Undang-undang Nomor 3 Tahun 2006 tentang Perubahan Undang-undang Nomor 7 Tahun 1989 tentang Peradilan Agama, bahwa Pengadilan Agama bertugas dan berwenang memeriksa, memutus, dan menyelesaikan perkara di tingkat pertama antara orang-orang yang beragama Islam. ${ }^{1}$ Lembaga yang memiliki kewenangan dalam menyelesaikan konflik atau perselisihan dalam keluarga khususnya masalah perceraian adalah Peradilan Agama $^{2}$.

Dalam Undang-undang Nomor 1 Tahun 1974 tentang Perkawinan pasal 39 ayat (1) memberikan ketentuan tentang perceraian hanya dapat dilakukan di depan pengadilan tentu setelah pengadilan berusaha berulangkali untuk mendamaikan kedua belah pihak agar perdamaian dapat terwujud. ${ }^{3}$ Maraknya perceraian di masa pandemi meningkat tajam hal ini terlihat di wilayah Propinsi Jawa Timur tepatnya dikabupaten mojokerto telah memutus perkara perceraian sebanyak 566 perkara selama masa pandemi corona virus ini $^{4}$, dimana perkara perceraian selama kurun waktu pada bulan maret-mei 2020 perkara perceraian lebih dominan diajukan oleh pihak perempuan atau cerai gugat (CG) sebanyak 421 perkara, sedangakan perkara cerai talak (CT) yang diajukan oleh laki-laki sebanyak 154 perkara. Melihat kenyataan ini perlu adanya sebuah terobosan yang dianggap mampu membendung laju perceraian.

Perceraian sangat berdampak secara psikologis pada kedua belah pihak, utamanya apabila telah memiliki anak, dinegara maju seperti Amerika Serikat telah mengutamakan kepentingan anak dalam menangani perkara perceraian, janiman kehidupan anak menjadi perhatian. Berbeda dengan di indonesia anak yang korban Broken Home cenderung akan menjadi anak yang kurang terurus. Sehingga dinegara majupun keadaan seperti ini berpotensi menciptakan kenakalan remaja. Dalam mendamaikan para pihak yang terlibat perselisihan

\footnotetext{
${ }^{1}$ Himpunan Peraturan Perundang-Undangan, Yogyakarta; Graha Pustaka, hlm 56

${ }^{2}$ Undang-undang No 3 Tahun 2006 tentang Perubahan atas Undang-undang nomor 7 tahun 1989 dalam Pasal 2 menyatakan Peradilan Agama adalah salah satu pelaku kekuasaan kehakiman bagi rakyat pencari keadilan yang beragama Islam mengenai perkara tertentu sebagaimana dimaksud dalam Undang-Undang ini.

3 Andri, Muhammad. "Diversity Adult Age Limits Positive Law In Indonesia (Studies in Multidisciplinary Perspective)." The 2nd Proceeding "Indonesia Clean of Corruption in 2020" (2017).

${ }^{4} \mathrm{https}$ ://news.detik.com/berita-jawa-timur/d-5049448/ada-566-janda-baru-di-mojokerto-s elama-tigabulan-pandemi-corona, diakses tanggal 16 juni 2020.
} 
dalam rumah tangganya diupayakan dengan mentahkim para pihak. Dan biasanya upaya melakukan perdamaian terhadap konflik rumah tangga dilakukan dengan musywarah, atau rekonsiliasi, mediasi, hal ini sebagai bagian dari metode Alternative Dispute Resolution yang telah berkembang di dunia barat, namun islam telah lebih dahulu menggunakan konsep shulh, yang biasakan digunakan dalam konflik suami dan istri. ${ }^{5}$

Bahwa kondisi wabah covid-19 ini membuat lembaga perkawinan ikut berdampak adanya virus ini, dimana seorang kepala keluarga tidak dapat melakukan kegiatan diluar rumah dengan nyaman dapat saja mereka merasa was-was keadaan ini dapat menularkan pada kelurganya. Namun sebelum wabah ini merebak mahkamah agung telah membuat kebijakan tentang pelaksanaan sidang secara online atau dapat disebut dengan e-court.

Perdamaian bagian dari budaya dan tradisi masyarakat, dalam Al Qur'an surat Al Baqarah 2: 182 dan 224, Al Hujurat 49: 9 dan 10 tentang perdamaian bagi mukmin yang perperang, Surat An Nisa' 4:128 perdamaian suami-isteri, dan An Nisa' 4:114 tentang anjuran untuk melakukan perdamaian sesama manusia. ${ }^{6}$ Mediasi juga telah ada dalam Dasar Negara Inonesia, yaitu Pancasila di mana dalam filosofinya bahwa asas penyelesaian sengketa adalah musyawarah ${ }^{7}$ untuk mufakat, dan juga tersirat dalam Undang-Undang Dasar $1945^{8}$. Menurut Satjipto Rahardjo ${ }^{9}$ banyaknya masyarakat menggunakan lembaga peradilan sebagai sarana untuk menggugat lawannya dikarenakan lembaga-lembaga tradisional yang dulu dipakai oleh masyarakat untuk menyelesaikan sengketa secara musywarah telah musnah oleh modernisasi. Kemudian lebih lanjut Satjipto Rahardjo ${ }^{10}$ mengemukakan " memang tidak dapat disangkal bahwa musyawarah untuk mufakat itu merupakan sebagian kekayaan kebudayaan indonesia. Namun dalam konteks masyarakat yang semakin terbuka dan individualistis serta pengorgasnisasian masyarakat secara modern rasional, maka pranata

${ }^{5}$ Muhammad Andri, Rekonstruksi Alternative Dispute Resolution (ADR) Sebagai Alternatif Penyelesaian Sengketa Perceraian Di Pengadilan Agama Yang Berbasis Keadilan, Semarang, Disertasi Program Doktor Ilmu Hukum Unissula, 2020, hal 5.

${ }^{6}$ Ibnu Qayyim Al-Jauziyah, I 'lam al-Muwaqqi'i'n an Rabb al-Alamin, (Beirut Daar al-Kutub al-Ilmiyah 1417/1996 (Jilid 1-lV)), diterjemahkan Asep Saefullah FM, Kamaluddin Sa'diyatulharamain, (Jakarta, Pustaka Azzam, 2000) hlm 101.

${ }^{7}$ Lihat, Nucholis Madjid, Islam Agama Kemanusiaan: Membangun Tradisi dan Visi Baru Islam Indonesia, (Jakarta: Paramadina, 1995), hlm. 194.

${ }^{8}$ Turan, Selahattin; Taylor; Title Alternative Dispute Resolution (ADR): A Different Framework for Conflict Resolution in Educational Settings, Paper presented at Annual Meeting of the National Council of Professors of Educational Administration (51st, Vail, CO, August 10-16, 1997). https://eric.ed.gov/?id=ED423206, diakses tanggal 17 Mei 2020

9 Lihat Satjipto Rahardjo, " Perilaku Gugat Menggugat" kompas, 25 Februari 1998 dalam Adi Sulistiyono, membangun paradigma penyelesaian sengketa non-litigasi dalam rangka pemberdayaan alternatif penyelesaian sengketa bisnis/hak kekayaan intelektual, Disertasi, (Semarang, pdih Undip, 2002), hlm. 21

${ }^{10}$ Lihat Satjipto Rahardjo, Hukum dan Masyarakat, Bandung, Angkasa, 1997, hlm 52. 
tersebut masih membutuhkan penyempurnaan secara kelembagaan serta penghayatan oleh masyarakat indonesia sendiri"

Namun sebelum adanya Undang-undang perkawinan. Badan Penasihatan Pembinaan dan Pelestarian Perkawinan (BP4) merupakan lembaga profesional yang memiliki tujuan sangat mulia yaitu membangun keluarga sakinah mawaddah dan warahmah, dengan cara memberikan penyuluhan, resolusi konflik suami isteri, menasehati, sehingga upaya BP4 dapat menurunkan angka perceraian pada zamannya. BP4 ini juga sebagai media untuk mendamaikan suami isteri yang terlibat konflik melalui hakam (mediator) dalam membantu para pihak $^{11}$. Semantara tingkat perceraian yang diajukan dipengadilan agama kian meningkat signifikan, sehingga membutuhkan upaya yang realistis dan konkret untuk mencari sebuah formula yang tepat. Zubaidah Muchtar seorang tokoh muslimah, konsultan, mediator di Pengadilan Agama, dan juga trainer mengatakan bahwa BP4 telah ikut menurunkan angka perceraian $10 \%$ dari $55 \%$ tahun 1955 menjadi $45 \%$ pada tahun $1966 .^{12}$

Dalam mediasi perceraian adalah suatu usaha untuk melakukan perdamaian dua orang suami dan isteri yang berselisih, dan dalam islam lebih dikenal dengan Tahkim dan (Shulh) karena telah memilik paranata yang sangat kuat di dalam Al-Qur'an seperti dalam QS AnNisaa` [4] : 35). Untuk mengurangi naiknya angka perceraian pemerintah melalui kemeterian agama mengeluarkan peraturan yang mewajibkan kursus calon pengantin "kursus pra nikah atau kursus calon pengantin (suscatin" $)^{13}$ upaya ini diharapakan dapat mengurangi boomingnya angka perceraian, karena akibatnya dari itu sangat merugikan anak yang terkait dalam lingkungan keluarga. Namun dalam masa pandemi Covid-19 perceraian dapat dilakukan dengan mematuhi protokol kesehatan karena mengutamakan keselamatan bersama lebih di utamakan. Walau kepentingan untuk menyelesaikan konflik antara suami dan isteri perlu dilakukan, namun tetap harus mejaga kondisi kesehatan. Serta perlu adanya instrumen hukum sebagai landasan hukum dimasa pandemi Covid-19 agar semua dapat berjalan sesuai harapan bersama.

Kemudian bagaimana implementasi shulh dalam perkara perceraian di masa pendemi covid-19 ini, sementara mereka membutuhkan penyelesaian permasalahannya agar tidak berlartu-larut dan mendapatkan kepastian hukum. Di sisi lain adanya jaga jarak yang juga

\footnotetext{
20 April 2020

${ }^{13}$ Andri, Muhammad. "Implementasi Bimbingan Perkawinan Sebagai Bagian Dari Upaya Membangun Keluarga Muslim Yang Ideal." ADIL Indonesia Journal 2.2 (2020).
}

${ }^{11}$ Muhammad Andri, Rekonstruksi Alternative Dispute....Op.cit

12 https://id.wikipedia.org/wiki/Badan Penasihatan Pembinaan dan Pelestarian Perkawinan, tanggal 
menggangu pelaksaan shulh di pengadilan, dan apabila dilakukan dengan media daring bagaimana dengan instrumen hukumnya sehingga shulh dengan melalui audio visual dapat dilakukan. Dengan pertimbangan urgensi shulh di masa pandemi covid-19 dalam perkara perceraian dapat menejadi media yang memberikan maslahat bagi para pihak.

\section{RUMUSAN MASALAH}

Berdasarkan latar belakang masalah diatas, maka dapat dirumusakan suatu rumusan masalah Dari uraian tersebut dapat di ambil suatu permasalahan yaitu bagaimana Urgensi Shulh dalam Perkara Perceraian di Pengadilan Agama selama masa Pandemi Covid-19?

\section{METODE PENELITIAN}

Dalam pembuatan sebuah karya ilmiah terutama karya ilmiah penelitian hukum diharuskan menggunakan metode penelitian hukum. Ilmu hukum berusaha untuk menampilkan hukum secara integral sesuai dengan kebutuhan kajian ilmu hukum itu sendiri, sehingga metode penelitian dibutuhkan untuk memperoleh arah penelitian yang komprehensif. $^{14}$ Sebenarnya ilmu hukum mempunyai ciri-ciri sebagai ilmu yang bersifat preskriptif dan terapan. Dalam preskriptif, ilmu hukum mempelajari tujuan hukum, nilai-nilai keadilan dalam suatu hukum, baik buruk suatu aturan hukum, konsep-konsep dan norma hukum. sedangkan dalam ilmu terapan, ilmu hukum menetapkan suatu prosedur, ketentuanketentuan dan batasan-batasan dalam menegakan suatu aturan hukum. ${ }^{15}$

Dalam tulisan ini penulis menggunakan metode penelitian yuridis normatif, penelitian ini bertujuan untuk mengetahui dan menganalisa tentang urgensi shulh dalam perkara perceraian di pengadilan agama selama masa pandemi covid-19. Bahwa dalam menjalani kegiatan diluar rumah selama masa pandemi covid-19 sangat mengkawatirkan bagi semua pihak, hal ini juga dapat terjadi pada suami dan isteri yang akan melakukan mediasi perceraian perlu adanya perangkat yang mendukung kegiatan tersebut selam masa pandemi covid ini. Dan pendekatan dilakukan dengan pendekatan perundang-undangan dengan sumberdata yang bertumpu pada bahan hukum kepustakaan, teori-teori hukum, artikel, dan

14 Yati Nurhayati, "Perdebatan Metode Normatif dengan Metode Empirik Dalam Penelitian Ilmu Hukum Ditinjau Dari Karakter, Fungsi dan Tujuan Ilmu Hukum”, Jurnal Al Adl, Volume 5 Nomor 10, 2013. Hal. 15.

\footnotetext{
${ }^{15}$ Yati Nurhayati, Pengantar Ilmu Hukum, Nusa Media, Bandung, 2020. Hal. 9.
} 
keputusan pengadilan, dan buku-buku yang relevan dengan kajian dalam penelitian ini. Kemudian data yang diperoleh di analisis dengan menggunakan metode desktiptif analisis yang bertujuan untuk mengetahui kejadian hukum yang berkembang dimasyarakat yang berkaitan dengan urgensi shulh dalam perkara perceraian dimasa pandemi covid-19.

\section{PEMBAHASAN}

Mendamaikan orang yang terlibat dalam perkara sangat dianjurkan dalam ajaran islam untuk didamaikan karena fitrahnya ${ }^{16}$ manusia tidak dapat hidup sendiri, kemudian Aristoteles dalam Moch Isnaeni juga menyatakan hal yang sama yaitu bahwa manusia itu juga disebut dengan "Zoon Politicon"17" manusia diciptakan cenderung memiliki rasa "komunal" atau "berkelompok" sehingga berpotensi ada ketersinggungan antara yang satu dengan yang lainnya.

Islam memberikan petunjuk penyelesaian perselisihan diantara manusia ini dengan berpedoman pada konsep Al Qur'an. Pengertian islah (shulh) menurut para ulama syafi'iyah adalah bahwa shulh adalah merupakan suatu akad yang dapat memutuskan pertikaian antara dua orang yang berperkara (berselisih). ${ }^{18}$

Konsep Islah atau berdamai dalam Islam sebenarnya juga merupakan konsep yang dianut oleh masyarakat sebagai bagian dari living law (hukum yang hidup) baik dalam hokum adat tiap daerah maupun yang kemudian diadopsi dalam hukum postitif dalam berbagai bentuk misalnya ada mediasi, konsiliasi, negosiasi atau arbitrase. ${ }^{19}$ Bahkan dalam perkembangan hukum terkini penyelesaian sengketa diluar pengadilan bukan hanya dilakukan dalam perdata tetapi juga dalam ranah sengketa pidana, misalnya penelitian mengenai mediasi

${ }^{16}$ Adi Hidayat lihat di https://www.youtube.com/watch? $v=0 R g t R E 28 E O I \& t=97 s$, diakses tanggal 17 agustus 2018 dalam Muhammad Andri, Rekonstruksi Alternative Dispute Resolution (Adr)Sebagai Alternatif Penyelesaian Sengketa Perceraian Di Pengadilan Agama Yang Berbasis Keadilan, Semarang, Disertasi Program Doktor Ilmu Hukum Unissula, 2020, hlm 79.

${ }^{17}$ Moch Isnaeni Moch. Isnaeni, Hukum Perkawinan Indonesia, Surabaya, Revka Petra Media, 2016, hlm, 1, dalam Muhammad Andri, Ibid

${ }_{18}^{18}$ Ahmad Wardi Muslich, Ahmad Wardi Muslich,2010, Fiqh Muamalah, Jakarta, Amzah.

19 Yati Nurhayati, The Finality of Arbitration : The Pros and Cons of the Courts Power To Setting Aside Arbitral Awards in Indonesia, Prosiding Internasional The $5^{\text {th }}$ International and Call Paper "Legal Reconstruction in Indonesia Based on Human Right”. Unissula Press, 2019, hlm. 376. Lihat juga AS Tornado, Yati Nurhayati dan Ifrani, The Doctrine of Public Policy As a Ground for The Anullment of Arbitral Award In Indonesia, The 4th International and call for Paper 2018, Unis sula Press, hlm. 204-210. 
penal dalam tindak pidana lingkungan hidup ${ }^{20}$ atau mediasi penal dan perkara pidana malpraktik dokter. ${ }^{21}$

Adapun dalam buku Fatwa dan Ijtihat Umar Bin Khatathab bahwa perdamaian dikalangan umat Islam itu dibolehkan, selama perdamaian tersebut tidak menghalalkan perkara yang haram atau mengharamkan yang halal. ${ }^{22}$ Kemudian umar berkata : "Hindarilah permusuhan, hendaknya mereka dapat menempuh dengan cara damai karena penyelesaian dengan hukuman itu dapat menimbulkan permusuhan di antara kaum". Umar juga berkata:" Hindarilah permusuhan mudah-mudahan mereka dapat menempuh dengan cara damai,karena hal itu dapat berpengaruh kepada kejujuran dan mengurang pengkhianatan selanjutnya Umar berkata:" Hindarilah permusuhan apabila diantara mereka ada ikatan keluarga karena penyelesaian dengan hukuman dapat mewariskan kebencian". ${ }^{23}$

Ishlah disebut dalam beberapa ayat al-quran yaitu Ishlah antar sesama muslim yang bertikai dan antara pemberontak (muslim) dan pemerintah (muslim) yang adil; Q.S.alHujurat49: 9-10;. Ishlah antara suami-isteri yang di ambang perceraian; dengan mengutus alhakam (juru runding) dari kedua belah pihak; Q.S.al-Nisa 4: 35. dan lain-lain;. Ishlah memiliki nilai yang sangat luhur dalam pandangan Allah,yaitu pelakunya memperoleh pahala yang besar (An-Nisa 4; 114);. Ishlah itu baik, terutama ishlah dalam sengketa rumah tangga(An-Nisa $4: 128){ }^{24}$

Mewabahnya virus covid-19 secara nyata mengubah pola dan perilaku manusia yang selama ini terbiasa dengan hal hal yang sudah dilakukan berubah 180 derajat semenjak virus ini. Salah satunya adalah model melakukan pernikahan yang harus mematuhi standart protokol kesehatan di negara indonesia dengan memakai masker dan menjaga jarak serta pembatasan jumlah 20 antrian. $^{25}$

Ketika seorang melakukan prosedur hukum perceraian di pengadilan agama dalam masa pandemi covid-19 dan new normal seperti saat ini, mereka harus melakukan hal -hal

${ }^{20}$ Nirmala Sari, Diana Haiti dan Ifrani, “Mediasi Penal Sebagai Alternatif Penyelesaian Perkara Tindak Pidana Lingkungan Hidup Pada Lahan Basah di Provinsi Kalimantan Selatan", Jurnal Al Adl, Volume VIII Nomor 1, Januari-April 2016, hlm. 2-7.

${ }^{21}$ Yati Nurhayati, "The Application of Balance idea In Settlement of Doctor Malpractice Case Through Penal Mediation", The 2nd Proceeding "Indonesia Clean of Corruption in 2020, Unissula Press, hlm. 111-117.

${ }_{22}$ Muhammad Abdul Aziz Al Hlmawi, 1999, Fatwa dan Ijtihat Umar Bin Khaththab : ensiklopedia berbagai persoalan fiqh, Risalah Gusti, Surabaya, hlm, 5.

${ }_{23}$ Ibnu Qayyim Al-Jauziyah, I 'lam al-Muwaqqi'i'n an Rabb al-Alamin, (Beirut Daar al-Kutub alIlmiyah 1417/1996 (Jilid 1-1V)), diterjemahkan Asep Saefullah FM, Kamaluddin Sa'diyatulharamain, (Jakarta, Pustaka Azzam, 2000) hlm 102

${ }^{24} \mathrm{https}: / / q u r a n . k e m e n a g . g o . i d /$, diakses tanggal 21 juni 2020.

$25 \mathrm{https}: / /$ news .okezone.com/read/2020/04/21/525/2202781/gugatan-cerai-menurun-di-tengah-pandemicorona, diakses 21 juni 2020 
yang tidak seperti biasanya, seperti menjaga jarak dalam antrian, memakai masker, dan sering mencuci tangan, hal-hal semacam ini mungkin baru kali ini terlihat dan ini akan menjadi pola hidup baru bagi umat manusia.

\section{A. Landasan Hukum Mediasi Perceraian Di Masa Pandemi Covid -19}

Menjalani kegiatan diluar rumah selama masa pandemi covid -19 ini sangat rentan terhadap virus yang mematikan ini. Menurut beberapa ahli bahwa visrus ini sangat mematikan, sehingga mengganggu aktivitas suami dan isteri yang akan melakukan shulh atau mediasi di pengadilan akibat konflik rumah tangganya. Bahwa penyelesaian perceraian dengan shulh sangat dianjurkan dalam islam sesuai dalam QS 4:35.

Dalam implementasi pelaksanaan shulh di masa pandemi covid-19 perlu adanya instrumen hukum yang memadai sebagai pedoman bagi mereka akan mengajukan perkara di pengadilan. Dalam persidangan di Pengadilan Agama dapat saja dilakukan dengan model daring atau virtual yaitu menggunakan perangkat audio visual sebagai jawaban atas kondisi seperti ini, dan ini telah dipersiapkan oleh mahkamah agung sudah sejak lama karena untuk menjalankan rencana strategis mahkamah agung yang sangat visioner.

Ketentuan seperti ini di terapkan dalam perma nomor 1 tahun 2016 pasal 5 ayat (3) menunjang pelaksanaan mediasi dengan sarana audio visual atau lebih viral dikatakan daring. Aturan tentang pelaksanaan daring ini telah di rencanakan sejak tahun 2016 untuk pelaksanaan mediasi, dengan demikian penulis menganggap tidak ada alasan wabah covid mengganggu pelaksanaan mediasi perceraian di pengadilan agama dan dapat dilakukan melalui model virtual. ${ }^{26}$ Kemudian dalam pasal 6 (2) behwa kehidaran para pihak (suami dan isteri) dalam audio visual dianggap merupakan kehadiran secara langsung. 27

Dalam peraturan Mahkamah Agung Nomor 1 Tahun 2019 tentang Administrasi Perkara dan Persidangan di Pengadilan secara Elektronik. Bahwa visi Mahakamah Agung telah jauh kedepan hal ini nampak jelas dalam Peraturan Mahkamah Agung (Perma) Nomor 3 Tahun 2018 tentang Administrasi Perkara secara elektronik dipengadilan, kemudian dikembangkan oleh Mahkamah Agung menjadi e-litigation berdasarkan Perma Nomo 1 Tahun 2019 artinya bila kita melihat kesiapan Mahkamah Agung telah siapa sejak sebelum

\footnotetext{
${ }^{26}$ https://batam.tribunnews .com/2020/04/27/3-bulan-corona-di-batam-726-kasus-perceraian-diajukanistri-dengan-usia-mayoritas-25-30-tahun?page=all, diakses tanggal 21 Juni 2020.

${ }^{27}$ Pasal 6 ayat (2) Perma Nomor 1 Tahun 2016 Tentang Mediasi Di Pengadilan Agama
} 
hadirnya wabah Covid-19 ini dengan model pencanangan e-litigation atau e-court sejak tahun $2018 .^{28}$

Namun demikian setelah wabah dianggap berkurang maka berlaku era new normal, mediasi tetap menggunakan pedoman protokol kesehatan. Dengan mematuhi aturan yang ada, serta membiasakan hidup dengan pola dan aturan sesuai dengan protokol kesehatan, serta mengikuti anjuran dari pemerintah sesuai dengan Tata Cara Pelaksanaan Perkawinan: Akad Nikah pada Masa Pandemi Covid-19 Dirjen Bimas Islam, Kamarudin Amin, pada 19 Maret 2020: Surat Edaran Nomor: P-002/DJ.III/hk.00.7/3/2020, tanggal 19 Maret 2020. (1). Membatasi jumlah orang yang mengikuti proses akad nikah dalam satu ruang tidak dapat lebih dari 10 orang. (2). Calonpe ngantin dan anggota keluarga yang mengikuti proses akad nikah harus membasuh tangan dengan sabun atau handsanitizer dan menggunakan masker. (3). Petugas KUA, Wali Nikah, dan Calon Pengantin laki-laki harus menggunakan sarung tangan dan masker pada saat ijab Kabul. ${ }^{29}$

Dalam rangka mewujudkan Peradilan Agama modern berbasis teknologi informasi dan pelayanan publik yang prima serta mendukung pencegahan penyebaran Covid-19, Direktorat Jenderal Badan Peradilan Agama Mahkamah Agung RI sebagaimana melalui surat Dirjen Badilag MA RI Nomor 1322/ DjA/HM.01/4/2020 tanggal 16 April 2020 sebagaimana tindak lanjut dari SEMA Nomor 1 Tahun 2020 yang mana telah dirubah dengan SEMA Nomor 3 Tahun 2020, bahwa Dirjen Badilag meluncurkan aplikasi internal yakni aplikasi VISION (Virtualisasi Surat Izin Online) yang dimanfaatkan oleh seluruh Peradilan Agama serta aplikasi gugatan mandiri yang dapat dimanfaatkan oleh seluruh para pencari keadilan. ${ }^{30}$

\section{B. Urgensi Shulh Pada Perkara Perceraian}

Perceraian tidak mengenal waktu, kapan pun perceraian ini terjadi saat itulah shulh harus dilakukan demi kebaikan bersama. Mencari solusi dengan mendamaikan tidak mencari kesalahan satu dengan yang lainnya. Dengan menghadirkan perwakilan masing-masing untuk melakukan perundingan dan para pihak yang bertikai menunggu hasil dari pertemuan itu

${ }^{28}$ Mukti Arto, Penanganan Perkara Perceraian dan Perkara Keluarga lainnya (Bidang Perkawinan dan Kewarisan) dimasa Pandemi. Disampaikan dalam Webinar dengan tema " Dampak Covid 19 Terhadap Mekanisme Dan Keabsahan Nikah Cerai Talak Dan Rujuk Di Indonesia”, diselenggarakan oleh Asosiasi Dosen Hukum Is lam: Web Seminar Nasional Kamis21 Mei 2020.

${ }^{29}$ Bisnis.com-https://kabar24.bisnis .com/read/20200320/15/1215869/begini-aturan-menikah-dt-kua-dimasa-covid-19, diakses taggal 21 juni 2020, lihat dalam Neng Djubaedah, yang di sampaikan dalam webinar dengan tajuk "Dampak Covid 19 Terhadap Mekanisme Dan Keabsahan Nikah Cerai Talak Dan Rujuk Di Indonesia", diselenggarakan oleh Asosiasi Dosen Hukum Islam: Web Seminar Nasional Kamis21 Mei 2020.

${ }^{30} \mathrm{https}: / /$ pa-probolinggo.go.id/Optimalis asi-Aplikasi-Layanan-dari-Dirjen-Badilag-pada-masa-PandemiCovid-19, diakses tanggal 21 juni 2020. 
dirumah, mengapa hal demikian ini dilakukan, sebab apabila para pihak ikut serta hadir dalam pertemuan sedang mereka dalam suasa emosi, maka tidak akan menemukan titik solusi yang baik sesuai konsep Al Qur'an 4;35.

Urgensi shulh dalam perceraian di masa pandemi sangat penting dan di perlukan oleh para pihak sebagai settlement. Untuk mendapatkan keputusan yang baik dan dapat diterima. Hal demikian telah terdapat ketentuan hukum dalam men-shulh perkara perceraian, dan tidak bisa dijadikan alasan adanya kendala wabah covid-19 ini sebagai force majure yang dijadikan alasan peniadaan mediasi (shulh).

Karena terjadinya perceraian dimasa pandemi covid -19 ini perlu diminimalisir dengan memberikan penyuluhan dan meningkatkan wawasan dan pengetahuan, serta perekonomian masyarakat yang turut serta menjadi faktor penyebab tingginya angka perceraian dikalangan suami istri pada masa pandemi Covid-19 ini hal yang perlu ditingkat juga adalah kesadaran suami istri perlu ditumbuhkan sebab para suami yang tidak bisa beraktivitas saat wabah ini.

Pencegahan perceraian dengan upaya shulh melalui perwakilan keluarga para pihak suami dan isteri yang dipertemukan dalam suasana kekeluargaan sehingga pendekatan ini menghasilkan sebuah keputusan yang baik untuk kedua pihak. Selain itu bentuk pencegahan lainnya adalah dengan model penyuluhan dimasyarakat sebagai upaya pemahaman tentang seluk beluk pernikahan dan tugas serta tanggung jawab bagi suami dan isteri. Pandemi covid19 ini merupakan ujian bagi seluruh manusia yang hidup di masa ini, karena merubah tatanan sosial di masyarakat, merubah pola berhubungan manusia satu dengan lainnya, begitu pula pada perkawinan berubah sebab adanya wabah ini.

\section{PENUTUP}

\section{A. Kesimpulan}

Bahwa men-shulh perkara perceraian merupakan hal yang sangat penting dalam implementasinya shulh pada perkara perceraian dipengadilan agama telah berbasis aplikasi online dengan model e litigation atau e court dalam hal ini sesuai dengan Perma Nomor 1 Tahun 2019 tentang Administrasi Perkara dan Persidangan di Pengadilan secara Elektronik, serta dapat dilihat turunan peraturan Mahkamah Agung sesuai dengan Perma Nomor 3 Tahun 2018 tentang Administrasi Perkara secara elektronik dipengadilan kemudian dikembang menjadi e-court, maka dengan adanya wabah covid-19 upaya mendamaikan para pihak yang 
ingin bercerai dilakukan dengan daring atau menggunakan perangkat audio visual yang menunjang kegiatan shulh dimasa pandemi covid-19 ini.

\section{B. Saran}

Bahwa dengan perkembangan zaman serta menuju revolusi industri 4.5 perlu dipersiapkan perangkat yang menunjang kerja lembaga, karena kondisi global secara kasat mata terus mengikuti arus modernisasi teknologi, seperti yang terjadi di era 2019 akhir terjadinya wabah covid menghentakkan seluruh jagad raya untuk mengantisipasi segala kemungkinan yang terjadi. Sehingga perlu dikembangkan perangkat yang berbasis tekologi informasi dalam segala aspek kehidupan, begitu juga dalam perkara mediasi dipengadilan dengan model daring sangat penting dipertahan dan ditingkatkan layanannya sebagai skala prioritas untuk kenyamanan masyarakat luas.

\section{Buku}

\section{DAFTAR PUSTAKA}

Ahmad Wardi Muslich (2010), Fiqh Muamalah, Jakarta : Amzah.

Ibnu Qayyim Al-Jauziyah, I 'lam al-Muwaqqi'i'n an Rabb al-Alamin, (Beirut Daar al-Kutub al-Ilmiyah 1417/1996 (Jilid 1-lV), 2000, diterjemahkan Asep Saefullah FM, Kamaluddin Sa'diyatulharamain, Jakarta : Pustaka Azzam.

Himpunan Peraturan Perundang-undangan, Yogyakarta; Graha Pustaka.

Satjipto Rahardjo, (1997), Hukum dan Masyarakat, Bandung : Angkasa.

Muhammad Abdul Aziz Al Hlmawi, 1999, Fatwa dan Ijtihat Umar Bin Khaththab : ensiklopedia berbagai persoalan fiqh, Risalah Gusti, Surabaya.

Nucholis Madjid, Islam Agama Kemanusiaan: Membangun Tradisi dan Visi Baru Islam Indonesia, (Jakarta: Paramadina, 1995).

Yati Nurhayati, Pengantar Ilmu Hukum, Nusa Media, Bandung, 2020.

\section{Peraturan Perundang-Undangan}

Undang Undang Dasar Negara Republik Indonesia 1945 Amandemen Tahun 2002

Undang-Undang No 3 Tahun 2006 tentang Perubahan atas Undang-Undang Nomor 7 Tahun 1989 tentang Pengadilan Agama. 
Undang-Undang Nomor 1 Tahun Tahun 1974 Tentang Perkawinan

Peraturan Mahkamah Agung Nomor 1 Tahun 2016 tentang Mediasi Di Pengadilan Agama

Peraturan Mahkamah Agung Nomor 3 Tahun 2018 tentang Administrasi Perkara Secara Elektronik Dipengadilan.

Peraturan Mahkamah Agung Nomor 1 Tahun 2019 Tentang Administrasi Perkara dan Persidangan di Pengadilan secara Elektronik.

\section{Jurnal dan Makalah}

Moch Isnaeni Moch. Isnaeni, Hukum Perkawinan Indonesia, Surabaya, Revka Petra Media, 2016, hlm, 1, dalam Muhammad Andri, Rekonstruksi Alternative Dispute Resolution (Adr)Sebagai Alternatif Penyelesaian Sengketa Perceraian Di Pengadilan Agama Yang Berbasis Keadilan, Semarang, Disertasi Program Doktor Ilmu Hukum Unissula, 2020.

Muhammad Andri, Rekonstruksi Alternative Dispute Resolution (Adr) Sebagai Alternatif Penyelesaian Sengketa Perceraian Di Pengadilan Agama Yang Berbasis Keadilan, Semarang, Disertasi Program Doktor Ilmu Hukum Unissula, 2020.

Satjipto Rahardjo, " Perilaku Gugat Menggugat" kompas, 25 Februari 1998 dalam Adi Sulistiyono, membangun paradigma penyelesaian sengketa non-litigasi dalam rangka pemberdayaan alternatif penyelesaian sengketa bisnis /hak kekayaan intelektual, Disertasi, (Semarang, pdih Undip, 2002).

Turan, Selahattin; Taylor; Title Alternative Dispute Resolution (ADR): A Different Framework for Conflict Resolution in Educational Settings, Paper presented at Annual Meeting of the National Council of Professors of Educational Administration (51st,Vail, CO, August 10-16,1997). https://eric.ed.gov/?id=ED423206, diakses tanggal 17 Mei 2020

Nirmala Sari, Diana Haiti dan Ifrani, "Mediasi Penal Sebagai Alternatif Penyelesaian Perkara Tindak Pidana Lingkungan Hidup Pada Lahan Basah di Provinsi Kalimantan Selatan", Jurnal Al Adl, Volume VIII Nomor 1, Januari-April 2016.

Mukti Arto, Penanganan Perkara Perceraian dan Perkara Keluarga lainnya ( Bidang Perkawinan dan Kewarisan) dimasa Pandemi. Disampaikan dalam Webinar dengan tema " Dampak Covid 19 Terhadap Mekanisme Dan Keabsahan Nikah Cerai Talak Dan Rujuk Di Indonesia”, diselenggarakan oleh Asosiasi Dosen Hukum Islam: Web Seminar Nasional Kamis 21 Mei 2020.

Neng Djubaedah, yang di sampaikan dalam webinar dengan tajuk "Dampak Covid 19 Terhadap Mekanisme Dan Keabsahan Nikah Cerai Talak Dan Rujuk Di Indonesia", diselenggarakan oleh Asosiasi Dosen Hukum Islam: Web Seminar Nasional Kamis 21 Mei 2020. 
Muhammad Andri "Implementasi Bimbingan Perkawinan Sebagai Bagian Dari Upaya Membangun Keluarga Muslim Yang Ideal." ADIL Indonesia Journal 2.2 (2020).

Muhammad Andri, "Diversity Adult Age Limits Positive Law In Indonesia (Studies in Multidisciplinary Perspective)." The 2nd Proceeding "Indonesia Clean of Corruption in 2020" (2017).

Yati Nurhayati, "Perdebatan Metode Normatif dengan Metode Empirik Dalam Penelitian Ilmu Hukum Ditinjau Dari Karakter, Fungsi dan Tujuan Ilmu Hukum", Jurnal Al Adl, Volume 5 Nomor 10, 2013.

Yati Nurhayati, "The Application of Balance idea In Settlement of Doctor Malpractice Case Through Penal Mediation", The 2nd Proceeding "Indonesia Clean of Corruption in 2020, Unissula Press.

AS Tornado, Yati Nurhayati dan Ifrani, The Doctrine of Public Policy As a Ground for The Anullment of Arbitral Award In Indonesia, The $4^{\text {th }}$ International and call for Paper 2018, Unissula Press.

Yati Nurhayati, The Finality of Arbitration : The Pros and Cons of the Courts Power To Setting Aside Arbitral Awards in Indonesia, Prosiding Internasional The 5th International and Call Paper "Legal Reconstruction in Indonesia Based on Human Right”. Unissula Press, 2019.

Mukti Arto, Penanganan Perkara Perceraian dan Perkara Keluarga lainnya ( Bidang Perkawinan dan Kewarisan) dimasa Pandemi. Disampaikan dalam Webinar dengan tema " Dampak Covid 19 Terhadap Mekanisme Dan Keabsahan Nikah Cerai Talak Dan Rujuk Di Indonesia", diselenggarakan oleh Asosiasi Dosen Hukum Islam: Web Seminar Nasional Kamis 21 Mei 2020.

Neng Djubaedah, yang di sampaikan dalam webinar dengan tajuk 'Dampak Covid 19 Terhadap Mekanisme Dan Keabsahan Nikah Cerai Talak Dan Rujuk Di Indonesia", diselenggarakan oleh Asosiasi Dosen Hukum Islam: Web Seminar Nasional Kamis 21 Mei 2020.

\section{Internet}

Adi Hidayat : https://www.youtube.com/watch?v=0RgtRE28EOI\&t=97s, dalam Muhammad Andri, Rekonstruksi Alternative Dispute Resolution (Adr) Sebagai Alternatif Penyelesaian Sengketa Perceraian Di Pengadilan Agama Yang Berbasis Keadilan, Semarang, Disertasi Program Doktor Ilmu Hukum Unissula, 2020.

Bisnis.com-https://kabar24.bisnis.com/read/20200320/15/1215869/begini-aturan-menikah-dtkua-di-masa-covid-19, diakses taggal 21 juni 2020.

https $/ /$ news.detik.com/berita-jawa-timur/d-5049448/ada-566-janda-baru-di-mojokertoselama-tiga-bulan-pandemi-corona, diakses tanggal 16 juni 2020. 
https:/id.wikipedia.org/wiki/Badan_Penasihatan_Pembinaan_dan_Pelestarian_Perkawinan, tanggal 20 April 2020

https $/ /$ pa-probolinggo.go.id/Optimalisasi-Aplikasi-Layanan-dari-Dirjen-Badilag-pada-masaPandemi-Covid-19, diakses tanggal 21 juni 2020.

Okezone: $\quad$ https://news.okezone.com/read/2020/04/21/525/2202781/gugatan-cerai-menurundi-tengah-pandemi-corona, diakses 21 juni 2020

Tribunnews:https:/batam.tribunnews.com/2020/04/27/3-bulan-corona-di-batam-726-kasusperceraian-diajukan-istri-dengan-usia-mayoritas-25-30-tahun?page=all, diakses tanggal 21 juni 2020 . 